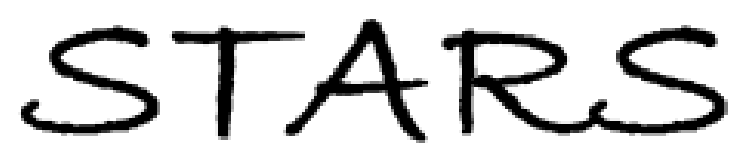

Journal of Health Occupations

Education

Volume 6 | Number 1

Article 9

1991

\title{
High Blood Pressure: The Silent Killer
}

\section{Sara Cameron R.N.}

Coosa County Area Vocational Center

Find similar works at: https://stars.library.ucf.edu/jhoe

University of Central Florida Libraries http://library.ucf.edu

This Video Review is brought to you for free and open access by STARS. It has been accepted for inclusion in Journal of Health Occupations Education by an authorized editor of STARS. For more information, please contact STARS@ucf.edu.

\section{Recommended Citation}

Cameron, Sara R.N. (1991) "High Blood Pressure: The Silent Killer," Journal of Health Occupations Education: Vol. 6 : No. 1 , Article 9.

Available at: https://stars.library.ucf.edu/jhoe/vol6/iss1/9

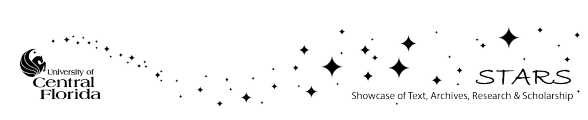


Cameron: High Blood Pressure: The Silent Killer

Video Review

High Blood Pressure: The Silent Killer (video), W. R. Spence, M.D., Health Edco, Inc., Waco, Texas.

High Bled Pressure: The Silent Killer introduces students to the seriousness of high blood pressure and its effect on the body. Blood pressure and abnormal readings are defined.

The video contains 40 frames that explain the disease process of high blood pressure, its effect on the patient, and risk factors of high blood pressure. Secondary diseases of heart, brain, kidneys, pancreas, and eyes and how untreated high blood pressure affects these body systems are made visually known to the viewer by showing tissue samples of patients that have high blood pressure. Emphasis is placed on the percentage of the population that has high blood pressure as well as the number of persons who die from this disease. The prevention and treatment for high blood pressure is also included.

Strengths of the video include photographs comparing normal tissue to diseased tissue and the accompanying booklet. The booklet assists the teacher in presenting the video and provides an explanation of each frame. Review questions to measure student knowledge are included in the booklet.

Sara Cameron, R.N., Instructor, Health Occupations Education, Coosa County Area Vocational Center, Rockford, Alabama. 